YU Haibo, FANG Liluo, LING Wenquan

\title{
An empirical study on the construct and effective mechanism of organizational learning
}

\author{
(C) Higher Education Press and Springer-Verlag 2009
}

\begin{abstract}
The organizational learning construct and its effective mechanism are two research issues. This study is based on a survey of 908 managers and employees from 43 companies in different regions of China. The results of exploratory factor analysis (EFA) and confirmatory factor analysis (CFA) show that organizational learning in Chinese enterprises is a multi-dimensional construct comprising of inter-organizational learning, organization-level learning, collective learning, individual learning, exploitation learning and exploration learning. The results of hierarchical linear modeling (HLM) reveal that the unit-level dimensions of organizational learning affect employee's satisfaction and emotional commitment through the mediation of individual learning. In organizations characterized by high level of organization-level learning and low level of exploitation learning, there is a strong correlation between employees' satisfaction/emotional commitment and their turnover intention. Hierarchical regression analysis (HRA) also indicates that organizational learning affects perceived organizational financial performance through the full mediation of organizational innovation. Some implications are discussed for organizational learning research and practice.
\end{abstract}

Translated and revised from Guanli Kexue Xuebao 管理科学学报 (Journal of Management Sciences in China), 2007, 10(5): 48-61

YU Haibo $(\triangle)$

School of Management, Beijing Normal University, Beijing 100875, China

Email: yuhb@bnu.edu.cn, yuhbnu@yahoo.com.cn

FANG Liluo

Institute of Psychology, Chinese Academy of Sciences, Beijing 100101, China

Email: fangll@psych.ac.cn

LING Wenquan

School of Management, Jinan University, Guangzhou 510632, China

Email: tlwq@jnu.edu.cn 
Keywords organizational learning, hierarchical linear modeling, mediator, moderator, learning organization

摘要 组织学习的结构和作用机制是组织学习研究中的两个迫切需要解决的基本问 题。根据访谈、编码和预试, 对来自全国不同地区 43 家企业的 982 名管理者和员工 的问卷调查数据进行了分析。探索性和验证性因素分析结果表明, 中国企业的组织 学习包括组织间学习、组织层学习、集体学习、个体学习、利用式学习、开发式学 习六个因素。多层线性模型结果表明, 组织学习集体层面的四个维度通过个体学习 影响员工的满意度和情感承诺; 在组织层学习水平高和利用式学习水平低的组织里 面, 满意度、情感承诺对离职意向的预测力更强。多层回归分析结果表明, 组织学 习通过组织创新来影响组织财务绩效。这些结果对组织学习的研究和管理实践都有 很重要的启发。

关键词 组织学习, 多层线性模型, 中介变量, 调节变量, 学习型组织

\section{Organizational learning: Concept and model development}

\subsection{Organizational learning concept}

Since March's (1958) introduction of the concept, organizational learning has drawn attention from researchers of different disciplines for more than half a century. Two problems, however, remain unsolved. First, due to a plethora of different concepts of organizational learning, there has been much more theoretical discussion than empirical studies in the field. Second, no widely accepted conclusion has been reached concerning the effects of organizational learning. As these two problems are of fundamental significance to theory building and organizational learning practice, research effort to resolve them becomes a high priority.

DiBella and Nevis (1998) suggested that there are three approaches to organizational learning research, namely normative approach, developmental approach and capability approach. This study adopts the third one, which argues that there are both conscious and unconscious learning behaviors in organizational learning. These behaviors vary in their learning capabilities. We concentrate in this paper on the process of organizational learning. In the literature, different viewpoints on organizational learning have been divided into three categories, namely the system and behavior view, information processing view, and social interaction view (Yu et al., 2004). Each of them emphasizes one or several aspects of organizational learning.

More specifically, researchers holding the system and behavior view of 
organizational learning emphasize the interaction between an organization and its environment. For example, Hedberg (1981) suggested that learning originates from adaptive and manipulative interactions between an organization and its environment. He also pointed out that organizational learning includes both the process by which organizations adjust themselves defensively to reality and the process by which knowledge is used offensively to improve the fitting between organizations and their environments. Hedberg's study provided a framework for the view of system and behavior on organizational learning. However, the study overlooked the micro process of organizational learning within an organization.

The information processing view of organizational learning focuses on the process of production, acquirement, dissemination, and application of new knowledge. In Huber's (1991) view, an entity learns if, through its processing of information, the range of its potential behaviors is changed. He also pointed out that organizational learning is composed of knowledge production, dissemination, and application. The information process view underlines most of the empirical studies in the field (e.g., Templeton et al., 2002; Tippins and Sohi, 2003; Ellis and Shpielberg, 2003; Jerez-Go'mez et al., 2004).

Scholars holding the social interaction view argue that organizational learning emerge amid the social interactions of employees. Senge (1990) emphasized the interaction among employees on the base of personal mastery in his concept of organizational learning. Cook and Yanow (1993) suggested that organizational learning is a formal or informal collective process of exploration and practice, and it is a cultural phenomenon. They emphasized that organizational learning is a phenomenon of collective learning. The introduction of communities of practice by Brown and Duguid (1991) is also considered as a social interaction process of learning. This view of organizational learning highlights the critical importance of employees in organizational learning.

Drawing on the literature reviewed above, we can summarize some of the basic characteristics of organizational learning: (1) It is a social interaction process, by which new knowledge is produced, disseminated, and applied; (2) It contains four levels, namely the individual, collective, organizational and inter-organization levels; (3) It is a process of collective learning and practice (Yu et al., 2004).

Therefore, from the perspective of organizational learning management, we conceptualize organizational learning as a continuous improvement process of organizational ideas or behaviors based on the individual employees' interactions with other knowledge agents both inside and outside an organization.

\subsection{Organizational learning model}

There are many models of organizational learning, some of which are based on the 
view of learning levels; others on information processing. Crossan et al. (1999) proposed a dynamic model which was empirically verified in later studies (e.g., Bontis and Crossan, 2002). Drawing on the views of Crossan et al. (1995) and Holmqvist (2003), we argue that organizational learning contains four levels, including individual level, collective level, organizational level and interorganization level. Also, Edmondson (1999) once pointed out that there are two approaches to organizational learning in literature, namely the result approach and process approach. We will focus on the process approach in this article. In addition, we develop an integrative model of organizational learning as in Fig. 1.

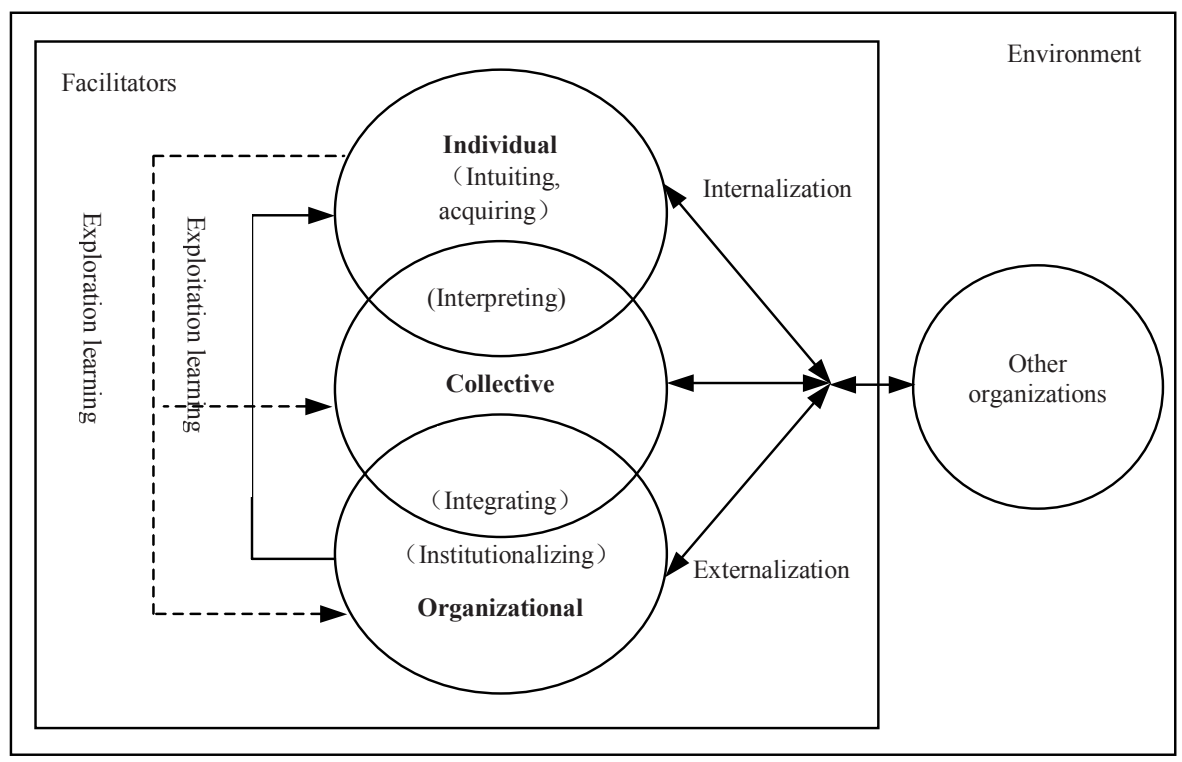

Fig. 1 An integrative model of organizational learning

Based on this model, this research will explore the dimensions of organizational learning and their respective effects on individuals and organizations in Chinese enterprises.

\section{Literature on organizational learning construct and its effects}

\subsection{Organizational learning construct}

Among the existing studies on organizational learning construct, no consistent results have been reached. Goh and Richards (1997) identified five 
organizational learning dimensions, including experiment, knowledge transfer, teamwork, leadership role and mission clarity. The results of Templeton et al (2002) showed that organizational learning construct composed of eight dimensions such as awareness, communication, performance assessment, intellectual cultivation, environmental adaptability, social learning, intellectual capital management, and organizational grafting. In comparison, Hult's and Ferrell's (1997) study was more exhaustive with regard to the validation of the scale. They designed 23 items to measure the four dimensions of organizational learning, namely team orientation, systems orientation, learning orientation, and memory orientation. In their study, Jerez-Go'mez et al. (2005) defined the different dimensions within organizational learning as management commitment, systems perspective, knowledge transfer and integration, openness and experimentation.

To date, there have been only several empirical studies on organizational learning in the Chinese context. Among them, Chen (2001) constructed one organizational learning model called 6P-1B consisting of seven dimensions: discovering, innovating, selecting, executing, transferring, reflecting, and knowledge base. $\mathrm{Wu}$ (2003) developed a seven-dimension model: clarity of objectives and task, leaders' commitment and empowerment, experimentation and motive, knowledge transfer, employee education and training, teamwork, organizational culture. Taken together, there are few common dimensions among the above studies due to different paradigms and approaches used. Specifically, out of the three approaches to organizational learning construct study (Yu et al, 2004), a majority of the above study adopted the approach of information processing and conceptualized organizational learning at the organizational level. However, organizational learning contains several levels (Easterby-Smith et al., 2000). In addition, much of the research collected data only from one employee, neglecting the nature of social interactions of organizational learning. To our best knowledge, there have been few empirical studies integrating all the above three approaches and adopting the perspective of learning management. Since organizational learning is initiated and conducted by employees, when exploring concrete dimensions of organizational learning, we should emphasize the social interaction among employees. Social interaction, however, involves complex knowledge or information processing process and organizational changes. Empirical study is required to verify the organizational learning dimensions proposed.

\subsection{Organizational learning effects and hypothesis development}

There has been little empirical study on organizational learning, particularly on the relationships between organizational learning and other relevant variables. At 
the individual level, Goh et al. (2002) explored the relationship between his five-dimension organizational learning capability and job satisfaction. The results showed that organizational learning relates strongly and significantly with job satisfaction (correlation coefficient is 0.66, p <0.001). Howard (2003) examined the relationship between organizational learning culture and organizational commitment and found a significant correlation between the two. We thus assume the following hypotheses:

H1 Organizational learning is positively related to employee satisfaction.

H2 Organizational learning is positively related to emotional commitment.

H3 Organizational learning is positively related to turnover intention.

Because this study examines organizational learning from several different levels, the interactions among different levels need to be taken in consideration (Hackman, 2003). In our model, individual learning is the only variable at the individual level. Possible mediation effects of individual learning may exist between unit-level organizational learning and individual employee's job attitudes. Accordingly, the following hypotheses are developed:

H4 Individual learning has a mediating effect on the relationship between unit-level learning and employees' job attitudes.

H5 Unit-level learning dimensions moderate the relationship between employee job attitudes and job behaviors.

Much research has been conducted on the relationship between organizational learning and organizational variables at the organizational level. For organizational innovation, Slater and Narver (1995) argued that organizational innovation has effects on organizational learning. Similarly, the results of Hurley (1998) and Hult et al. (2003) showed that organizational learning correlates significantly with organizational innovation. Calantone et al. (2002) investigated 187 R\&D senior managers, and the confirmatory factor analysis showed the coefficient of learning orientation and organizational innovation capability is $0.49(p<0.01)$. So, We argue that organizational learning can facilitate organizational innovation and thus it can affect organizational innovation positively.

H6 Organizational learning is positively related to organizational innovation.

Some studies have demonstrated that organizational organizational learning and innovation affects organizational performance. Both positive and negative 
evidence has been provided. The results of Yang et al. (2004) showed that the coefficient of one dimension of their learning organization questionnaire and knowledge performance is 0.35. Similarly, Hult et al. (2003) found that learning orientation was positively correlated with organizational performance. Chen et al. (2005) also concluded that the seven dimensions of organizational learning significantly correlate with organizational performance (the correlations coefficients range from 0.64 to 0.74 ). Direct positive relation between organizational learning and financial performance has also been supported by other empirical studies, such as Ellinger et al. (2002), Tippins and Sohi (2003) and Argote and Ingram (2000). Among these results, Calantone et al. (2002) found that organizational innovation is an partial mediator between antecedent learning orientations and a firm's general performance. However, Goh et al. (2002) found no significant correlation between organizational learning and organizational financial performance. Yeung et al. (1999) surveyed 1532 employees from 268 companies in 40 countries. Their results showed that there are no strong direct correlations between organizational learning and organizational performance. So, We argue that organizational learning can affect organizational finance performance directly and indirectly, that is to say, organizational innovation is the partial mediator between organizational learning and finance performance. Therefore, we develop the other two hypotheses:

H7 Organizational innovation is positively related to perceived organizational financial performance.

H8 Organizational learning is positively related to perceived organizational financial performance.

The results of above research depict the effects of organizational learning on individual employee's job attitudes/behaviors and organizational innovation/performance. But three problems remain unsolved. First, extant research has neglected different levels of organizational learning and the nature of social interaction of organizational learning. Second, the complex effective mechanism of organizational learning on individual and organization has not been examined. Third, no consistent conclusions concerning the effects of organizational learning on organizational financial performance have been reached.

To solve the above problems, we will construct in this study a new and integrative organizational learning model and attempt to identify potential dimensions of organizational learning. Then we will explore the effective mechanisms of organizational learning on individual employees and organizations. 


\section{Organizational learning construct}

\subsection{Pilot study}

\subsubsection{Interview}

Because organizational learning is a new concept for employees in Chinese enterprises, we adopt interview as a means of exploring organizational learning behaviors. The procedures are as follows.

First, we showed the definition of organizational learning to the interviewees. Second, we had a discussion on the concept with the interviewees, and they described their companies' organizational learning behaviors. Third, after the interviewees had understood the concept, we conducted interviews as planned and gained deeper understanding of their companies' organizational learning behaviors. A total of 10 interviews with high and middle managers from 9 companies (three were state-owned enterprises, three Sino-foreign joint ventures, and three private enterprises) were conducted. Each of them lasted for about one and a half hours.

\subsubsection{Coding}

Two specialists in industrial and organizational psychology (both with a doctoral degree) were invited to code the 10 interview records. Before coding, the two specialists were informed in details the study plan, procedures and aims, and relevant theories and concepts of organizational learning. After reaching agreements with one another on the organizational learning theories and concepts involved, the two specialists started coding the documents of the above 10 interviews.

First, they randomly selected two documents and searched for organizational learning behaviors individually. After that, they combined their results to form the coding base. Second, they discussed the coding base according to the context of the interview documents and revised the organizational learning behaviors. Third, they searched for organizational learning behaviors separately based on the coding base. During these processes, they tried to search for all the organizational learning behaviors in the documents of interviews. Fourth, they combined and discussed their results. Altogether 53 organizational learning behaviors were obtained, which were coded according to a 3-point rating scale with 3 equals "positive assessment", 2 "neutral assessment", 1 "negative assessment", and 0 "did no mention". The conformity coefficient of the coding is 0.97 .

At last, we invited 6 experts and 4 managers to modify the above organizational learning behaviors according to their understandings. The resulting 53 organizational learning behaviors items were used to form the pilot 
questionnaire.

\subsubsection{Survey}

The questionnaire was conducted to a random sample of MBA students and part-time graduate students from Jinan University, South China Sciences and Technology University, and Central University of Finance and Economics. 123 valid questionnaires were received.

Each retrieved questionnaire was reviewed carefully in terms of the correlations between items and the sum, the skewness and kurtosis of the items, and the Cronbach $\alpha$. Accordingly, 37 items were identified to form the new questionnaire for the next step.

\subsection{Exploration of organizational learning construct}

\subsubsection{Participants and procedure}

982 employees from 43 Chinese companies in 9 cities participated in the study. 614 were chosen randomly to explore the construct of Chinese companies' organizational learning. $61.1 \%$ of the participants were from state-owned companies, $19.1 \%$ from non-governmental business, $10.3 \%$ from Sino-foreign joint ventures and $9.5 \%$ from other types of companies. In addition, $48.9 \%$ participants were from small sized companies with less than 1000 employees, $32.1 \%$ from middle sized companies with 1000 to 5000 employees, and $19.1 \%$ from large sized companies with more than 5000 workers. $64.6 \%$ participants were employees and $35.4 \%$ were managers.

\subsubsection{Measures}

Organizational learning. Organizational learning was measured by using the above 37 item questionnaire. Participants' perceptions of the extent to which their companies demonstrate learning behaviors were surveyed. All items used a 5 -point Likert-type scale ranging from 1 (strongly disagree) to 5 (strongly agree).

\subsubsection{Results}

The qualities of all questionnaire items were tested by calculating the correlations between items and the sum, the skewness and kurtosis and the Cronbach $\alpha .8$ unsuitable items were eliminated accordingly, resulting in a 29-item questionnaire. The first step in data analysis was to explore the factorial structure of the organizational learning questionnaire with the randomly selected 614 questionnaires. Exploratory Principle-component analysis (PCA) factor 
analysis with varimax rotation was performed. This yielded six factors that were identical to those revealed by the pretest sample (see Table 1), explaining $54.24 \%$ of the total variance. The six factors are named as follows: inter-organizational learning, exploration learning, exploitation learning, organization-level learning, collective learning, and individual learning.

Table 1 Results of Exploratory Factor Analysis of the organizational learning questionnaire $(N=614)$

\begin{tabular}{|c|c|c|c|c|c|c|}
\hline & Factor 1 & Factor 2 & Factor 3 & Factor 4 & Factor 5 & Factor 6 \\
\hline Item & $\begin{array}{l}\text { Inter-organi- } \\
\text { zational } \\
\text { learning }\end{array}$ & $\begin{array}{l}\text { Exploitation } \\
\text { learning }\end{array}$ & $\begin{array}{c}\text { Exploration } \\
\text { learning }\end{array}$ & $\begin{array}{l}\text { Organization- } \\
\text { level lear- } \\
\text { ning }\end{array}$ & $\begin{array}{l}\text { Collective } \\
\text { learning }\end{array}$ & $\begin{array}{r}\text { Individual } \\
\text { learning }\end{array}$ \\
\hline 25 & 0.639 & 0.254 & 0.308 & 0.085 & 0.217 & 0.009 \\
\hline 29 & 0.628 & 0.013 & 0.137 & 0.228 & 0.176 & 0.221 \\
\hline 5 & 0.596 & 0.175 & 0.113 & 0.113 & -0.083 & 0.255 \\
\hline 17 & 0.556 & 0.106 & 0.171 & 0.073 & 0.092 & 0.180 \\
\hline 37 & 0.527 & 0.134 & 0.261 & 0.275 & 0.093 & 0.071 \\
\hline 23 & 0.479 & 0.340 & 0.220 & 0.158 & 0.217 & 0.083 \\
\hline 9 & 0.074 & 0.770 & 0.073 & 0.168 & 0.141 & 0.141 \\
\hline 7 & 0.280 & 0.675 & 0.026 & 0.094 & 0.059 & 0.222 \\
\hline 10 & 0.036 & 0.636 & 0.403 & 0.169 & 0.044 & 0.149 \\
\hline 19 & 0.296 & 0.627 & 0.225 & 0.162 & 0.142 & 0.081 \\
\hline 35 & 0.238 & -0.010 & 0.707 & 0.108 & -0.046 & 0.043 \\
\hline 24 & 0.231 & 0.182 & 0.706 & 0.114 & 0.116 & 0.127 \\
\hline 20 & 0.295 & 0.274 & 0.687 & 0.056 & 0.105 & -0.006 \\
\hline 34 & 0.170 & 0.104 & 0.402 & 0.387 & 0.237 & 0.072 \\
\hline 12 & -0.023 & 0.192 & 0.106 & 0.742 & 0.071 & 0.191 \\
\hline 15 & 0.142 & 0.098 & 0.095 & 0.698 & 0.083 & 0.067 \\
\hline 33 & 0.291 & 0.328 & 0.053 & 0.560 & 0.259 & -0.102 \\
\hline 27 & 0.223 & 0.014 & 0.118 & 0.555 & 0.099 & 0.093 \\
\hline 4 & 0.165 & 0.466 & -0.029 & 0.515 & -0.042 & 0.211 \\
\hline 30 & 0.100 & 0.111 & -0.002 & 0.041 & 0.770 & 0.141 \\
\hline 21 & -0.020 & 0.124 & 0.188 & 0.115 & 0.671 & 0.126 \\
\hline 13 & 0.156 & 0.172 & -0.018 & 0.088 & 0.622 & 0.239 \\
\hline 28 & 0.174 & -0.113 & 0.157 & 0.203 & 0.604 & 0.195 \\
\hline 3 & 0.098 & 0.227 & 0.246 & 0.048 & 0.161 & 0.656 \\
\hline 8 & 0.207 & 0.056 & -0.027 & 0.142 & 0.128 & 0.614 \\
\hline 16 & 0.023 & 0.083 & 0.349 & 0.190 & 0.235 & 0.567 \\
\hline 1 & 0.287 & 0.267 & -0.163 & 0.066 & 0.119 & 0.552 \\
\hline 11 & 0.066 & 0.105 & 0.374 & 0.144 & 0.290 & 0.541 \\
\hline 6 & 0.247 & 0.095 & -0.169 & -0.008 & 0.387 & 0.490 \\
\hline $\begin{array}{l}\text { Eigen } \\
\text { value }\end{array}$ & 8.412 & 2.062 & 1.610 & 1.383 & 1.188 & 1.075 \\
\hline Variance & $9.73 \%$ & $9.66 \%$ & $8.96 \%$ & $8.69 \%$ & $8.65 \%$ & $8.56 \%$ \\
\hline
\end{tabular}


In this study, Individual learning refers to employees' improvement process on their jobs by continuous summarizing, exploring and practicing, based on clear work goals. That is to say, individual learning means employee's change of cognitions or behaviors caused by experience. Thus, although individual learning is not identical with organizational learning, individual learning is the necessary condition for the latter (Argyris and Schön 1978; Kim, 1993).

Collective learning here refers to the social interaction process that employees develop shared understanding and cooperative actions. That is to say, collective learning changes the cognitions or behaviors of employees. It is an ongoing process of reflection and action, characterized by questions asking, exploitation seeking, experimenting, results reflecting, and errors discussing or unexpected outcomes of actions (Edmondson, 1999).

Organization-level learning here refers to the integration of individual level learning and collective level learning to the organizational systems, structures, strategy, procedures and culture, so that they can adapt more easily to both internal and external environment. That is to say, organizational level learning embodies the enduring changes of such organizational characteristics as organizational structures, strategy and culture.

Inter-organizational learning here refers to the interaction between individual, collective, and organizational level of two or several organizations, so that they can acquire, produce, disseminate and apply new knowledge to change their cognitions and behaviors. In this process, there is much exchange of irregular information, and this helps them to acquire new knowledge and capability. Pedler (1991) considered inter-organizational learning as a major characteristic, and Nonaka and Takeuchi (1995) argued that knowledge innovation should be expanded to inter-organizational level. Crossan et al (1995) pointed out that organizational learning includes inter-organizational learning. In his theory of learning levels, Pawlowsky (2001) contended that inter-organizational learning level is an integrated part of organizational learning. For example, most Chinese companies need to strengthen their learning from their western counterparts for more rapid development.

Exploitation learning refers to the process that information flows from organizational level to collective level and individual level, and it is a process of knowledge exploitation (Crossan et al., 1999; March, 1991), in which individual's cognitions or behaviors can be changed. In fact, the essence of exploitation learning is the process of applying what has been learned (Holmqvist, 2003). This process is accomplished primarily by learning at the organizational level. Argyris and Schön (1978) argued that organization detects and corrects errors through single-loop learning. Similarly, Senge (1990) asserted that organization adapts new environment through adaptive learning, a lower level of learning (Fiol and Lyles, 1985). 
Exploration learning refers to a process in which information flows from individual level or collective level to organizational level. It is a process of knowledge exploration, of converting or integrating individual's new knowledge to organizational knowledge, so that the organizational level characteristics can be changed or modified according to the environment. This process is accomplished by higher level type of learning (Fiol and Lyles, 1985. Argyris and Schön (1978) argued that organization changes and modifies its basic action-theories through double-loop learning. Senge (1990) asserted that organizations produce new knowledge or theory by generative learning. However, many organizations lack this learning process in practice.

The results show that Cronbach's $\alpha$ of inter-organizational learning, exploitation learning, exploration learning, organization-level learning, collective learning, and individual learning are $0.77,0.78,0.75,0.73,0.71,0.76$, respectively. All Cronbach's $\alpha$ are above 0.70 and the $\alpha$ of the total scale is 0.91 , indicating a satisfactory internal consistency of the organizational learning questionnaire.

\subsection{Confirmation of organizational learning construct}

Explorative factor analysis on 368 participants shows that organizational learning consists of six factors. Based on relevant literature review, we can put forward other two hypothesized models (M3 refers to the measurement model).

First, is organizational learning a one-dimension model? To test it, the one dimension model (hypothesized model 1) is suggested.

Second, inter-organizational learning is neglected in organizational learning literature. And it is a distinctive feature of this study in comparison with other studies. Is organizational learning composed of inter-organizational learning and intra-organizational learning? To test it, the hypothesized Model 2 is developed.

Which model fits the data better? The results of the AMOS analysis are listed as follows (see Table 2).

Table 2 Results of confirmatory factor analysis of competing models

\begin{tabular}{crrrrrrrrr}
\hline Models & $\chi^{2}$ & $\boldsymbol{d} \boldsymbol{f}$ & $\chi^{2} / \boldsymbol{d} \boldsymbol{f}$ & NFI & IFI & TLI & CFI & PNFI & RMSEA \\
\hline M0 & 26412.6 & 435 & 60.72 & & & & & & \\
M1 & 32309.7 & 435 & 74.28 & 0.960 & 0.971 & 0.967 & 0.971 & 0.832 & 0.081 \\
M2 & 32309.7 & 435 & 74.28 & 0.961 & 0.955 & 0.968 & 0.973 & 0.831 & 0.080 \\
M3 & 1067.7 & 376 & 2.84 & 0.960 & 0.973 & 0.969 & 0.973 & 0.829 & 0.078 \\
\hline
\end{tabular}

Note: M0: null model; M1: one-dimension model; M2: two-dimension model (inter- and intraorganizational learning); M3: six-dimension model. The same in tables below.

As shown in Table 2, judging from values of $\chi^{2} / d f$ (the critical index is 3.0) and 
RMSEA (the critical index is 0.80) (Bollen, 1989; Medsker, Willams, Hoahan, 1994), M1 and M2 do not fit the data as good as M3, the six-dimension model. As shown in Table 3, for all items in M3, their factor loadings are considerably bigger than error loadings. Thus the results of the exploratory factor analysis and confirmatory factor analysis suggest that M3 is the best model for Chinese enterprise's organizational learning.

Table 3 Factor loadings and error loadings on items in the six-dimension model

\begin{tabular}{|c|c|c|c|c|c|c|c|c|}
\hline \multicolumn{3}{|c|}{ Individual learning } & \multicolumn{3}{|c|}{ Collective learning } & \multicolumn{3}{|c|}{ Organization-level learning } \\
\hline Item & $\begin{array}{l}\text { Factor } \\
\text { loading }\end{array}$ & $\begin{array}{l}\text { Error } \\
\quad \text { loading }\end{array}$ & Item & $\begin{array}{l}\text { Factor } \\
\text { loading }\end{array}$ & $\begin{array}{l}\text { Error } \\
\quad \text { loading }\end{array}$ & Item & $\begin{array}{l}\text { Factor } \\
\text { loading }\end{array}$ & $\begin{array}{l}\text { Error } \\
\quad \text { loading }\end{array}$ \\
\hline 3 & 0.631 & 0.398 & 30 & 0.534 & 0.285 & 12 & 0.629 & 0.396 \\
\hline 8 & 0.704 & 0.495 & 21 & 0.562 & 0.315 & 15 & 0.724 & 0.524 \\
\hline 16 & 0.621 & 0.386 & 13 & 0.624 & 0.389 & 33 & 0.613 & 0.376 \\
\hline 1 & 0.531 & 0.282 & 28 & 0.554 & 0.307 & 27 & 0.684 & 0.468 \\
\hline 11 & 0.740 & 0.548 & & & & 4 & 0.590 & 0.348 \\
\hline 6 & 0.493 & 0.243 & & & & & & \\
\hline \multicolumn{3}{|c|}{ Inter-organizational learning } & \multicolumn{3}{|c|}{ Exploitation learning } & \multicolumn{3}{|c|}{ Exploration learning } \\
\hline Item & $\begin{array}{l}\text { Factor } \\
\text { loading }\end{array}$ & $\begin{array}{l}\text { Error } \\
\quad \text { loading }\end{array}$ & Item & $\begin{array}{l}\text { Factor } \\
\text { loading }\end{array}$ & $\begin{array}{l}\text { Error } \\
\quad \text { loading }\end{array}$ & Item & $\begin{array}{l}\text { Factor } \\
\text { loading }\end{array}$ & $\begin{array}{l}\text { Error } \\
\quad \text { loading }\end{array}$ \\
\hline 25 & 0.643 & 0.413 & 9 & 0.759 & 0.576 & 35 & 0.612 & 0.374 \\
\hline 29 & 0.637 & 0.406 & 7 & 0.716 & 0.512 & 24 & 0.739 & 0.546 \\
\hline 5 & 0.527 & 0.278 & 10 & 0.710 & 0.505 & 20 & 0.740 & 0.547 \\
\hline 17 & 0.497 & 0.247 & 19 & 0.613 & 0.375 & 34 & 0.598 & 0.357 \\
\hline 37 & 0.582 & 0.338 & & & & & & \\
\hline 23 & 0.661 & 0.437 & & & & & & \\
\hline
\end{tabular}

\section{Effective mechanisms of organizational learning on individual employees}

\subsection{Measures}

Organizational learning. In this study, organizational learning was measured by using the above 29 item questionnaire.

Employee Satisfaction. Tsui et al.'s (1992) 6-item Scale was chosen to measure the degree of employees' total satisfaction to their enterprises. Participants were required to use a 5-point Likert-type scale to assess their agreement to each item: 1 stands for strongly disagree and 5 strongly agree, same as below; Cronbach $\alpha=0.74$ ).

Emotional commitment. Meyer et al's (1993) 6-item scale was chosen to measure the degree of employees' commitment to their companies (Cronbach 
$\alpha=0.86)$.

Turnover intention. Konovsky and Cropanzano's (1991) 6-item scale was chosen to measure the degree of employees' intention to quit their jobs (Cronbach $\alpha=0.78$ ).

\subsection{Test of the validity of the unit level variables}

Except for the individual level learning, all other five dimensions of organizational learning are unit level variables. Therefore, the first step is to test the validity criteria for all these unit-level variables.

Since all the five variables are shared phenomena (Kozlowski and Klein, 2000), drawing on Chan's (1998) view, we used the consensus model to design questionnaire items of the collective level learning subscale, and the referent-shift consensus model to design the questionnaire items of the other four unit level variables. Thus, aggregation of individual-level perceptions to unit level variable is desirable (Kozlowski and Klein, 2000; Zohar, 2000). We aggregated individual-level perceptions of the six variables to unit-level measures of these variables. To ensure the appropriateness of these aggregations, the validity criteria (i.e. within-group homogeneity and between group variation) of these variables must be obtained. We first assessed the degree of agreement for these unit level variables measures by calculating both the within-group inter-rater reliability statistic $\left(r_{w g}\right)$ statistic (James, Demaree, Wolf, 1984, 1993; Klein et al., 2000) (see Table 4). The $r_{w g}$ statistic reflects the degree of inter-rater agreement among members in a company, with 1.00 indicating perfect agreement across all members. Among the 43 companies in our sample, the mean and median of $r_{w g}$ for uniform and negative null distribution were all above 0.70 (Klein et al, 2000) (see Table 4), suggesting that aggregations was appropriate. Homogeneity can also be tested by the intra-class correlation coefficient (ICC) (Bartko, 1976; James, 1982). All the ICC(1)s of the five variables all fell in the range of $0-0.50$, consistent with James' (1982) findings in his study. The ICC(2)s for these ratings were all above 0.70 (Klein et al., 2000) (see Table 5), indicating that these companies can be reliably differentiated on individual perceptions of these unit level variables. Between groups variance were tested with one-way analysis of variance (ANOVA). These analyses were conducted with unaggregated data, using enterprise affiliation of each respondent as independent variable. Results indicated that these unit level variables exhibit a significant between-group variance (see Table 6). Together, the results suggest that there are sufficiently high with-group homogeneity and between-groups variance to justify the average of individual-level data as the measurement of these unit level variables. 
Table 4 Mean and media of $r_{w g}$ of all unit level variables

\begin{tabular}{llccccc}
\hline \multirow{2}{*}{$\begin{array}{c}\text { Null } \\
\text { distribution }\end{array}$} & $\begin{array}{c}\text { Collec- Organization- } \\
\text { tive }\end{array}$ & $\begin{array}{c}\text { Inter-organi- } \\
\text { level }\end{array}$ & $\begin{array}{c}\text { Exploita- } \\
\text { zational }\end{array}$ & $\begin{array}{c}\text { Explora- } \\
\text { tion }\end{array}$ \\
\hline \multirow{2}{*}{ Mean } & uniform & 0.88 & 0.90 & 0.89 & 0.85 & 0.82 \\
& negative & 0.90 & 0.92 & 0.91 & 0.82 & 0.85 \\
& uniform & 0.89 & 0.91 & 0.89 & 0.87 & 0.84 \\
& negative & 0.91 & 0.92 & 0.91 & 0.84 & 0.87 \\
\hline
\end{tabular}

Table 5 ICC (1) and ICC (2)of all unit level variables (average $N=21$ )

\begin{tabular}{lccccc}
\hline & Collective & $\begin{array}{c}\text { Organization- } \\
\text { level }\end{array}$ & Inter-organizational & Exploitation & Exploration \\
\hline ICC (1) & 0.09 & 0.23 & 0.21 & 0.25 & 0.12 \\
ICC (2) & 0.68 & 0.86 & 0.85 & 0.87 & 0.74 \\
\hline
\end{tabular}

Table 6 Test of between group differences for all unit level variables

\begin{tabular}{lcccc}
\hline & MSB & MSW & d.f. & $\boldsymbol{F}$ \\
\hline Collective learning & 1.075 & 0.342 & $42 / 863$ & $3.14^{* * *}$ \\
Organization-level learning & 2.189 & 0.305 & $42 / 863$ & $7.19^{\text {**** }}$ \\
Inter-organizational learning & 2.318 & 0.353 & $42 / 863$ & $6.57^{\text {*** }}$ \\
Exploitation learning & 3.849 & 0.486 & $42 / 863$ & $7.91^{\text {*** }}$ \\
Exploration learning & 1.874 & 0.495 & $42 / 863$ & $3.79^{* * *}$ \\
\hline
\end{tabular}

Note: ${ }^{* * *}$ indicates $p<0.001,{ }^{* *}$ indicates $p<0.01,{ }^{*}$ indicates $p<0.05$.

4.3 The direct effects of organizational learning on individual employee

Since employees' satisfaction, emotional commitment and turnover intention are individual level variables and organizational learning contains one individual level variable (individual learning) and five unit level variables, it is not suitable to use OLS or SEM to analyze the relationships between organizational learning and these three individual level variables. Thus cross-level analyses such as Hierarchical Linear Models (HLM) (Bryk and Raundenbush, 1992; Hofmann et al., 2003; Ambrose and Schminke, 2003) may be more appropriate .

The results of HLM are listed as follows: individual learning $(\gamma=0.41$, $p<0.001)$, collective learning $(\gamma=0.42, p<0.05)$, organization-level learning $(\gamma=0.40, p<0.01)$, inter-organizational learning $(\gamma=0.45, p<0.01)$, and exploration learning $(\gamma=0.44, p<0.01)$ all correlated positively with employee satisfaction; individual learning $(\gamma=0.33, p<0.001)$, organizational learning $(\gamma=0.45, p<0.05)$, inter-organizational learning $(\gamma=0.55, p<0.001)$, exploitation learning $(\gamma=0.37$, $p<0.01)$, and exploration learning $(\gamma=0.59, p<0.001)$ all correlated positively with employee emotional commitment; individual learning $(\gamma=-0.19, p<0.005)$ 
significantly and negatively correlated with employee turnover intention. Therefore, the hypotheses 1, 2, 3 are partially supported.

\subsection{The mediation effects of individual learning}

For a variable to act as a mediator, it must satisfy the following three conditions: (1) the independent variable must affect the mediator; (2) the independent variable must be shown to affect the dependent variable; and (3) regressing the dependent variable on both the independent variable and the mediator, the mediator must affect the dependent variable (Baron and Kenny, 1986). The results of HLM (Table 7) show that the independent variable (collective learning) correlates significantly with the mediator (individual learning) in M2 $\left(\gamma_{01}\right)$; the mediator affects significantly the dependent variable (employee satisfaction) in M3 $\left(\gamma_{10}\right)$; and the independent variable correlates significantly with the dependent variable in M4 $\left(\gamma_{01}\right)$. In M4, collective learning has a significant effect on employee satisfaction, but this effect diminishes in M5 when the mediator is controlled. We thus conclude individual learning is a full mediator between collective learning and employee satisfaction and the mediation effect size is $0.15([0.40-0.34] / 0.40)$.

Table 7 Individual learning as mediator between collective learning and employee satisfaction

\begin{tabular}{|c|c|c|c|c|c|c|c|}
\hline \multirow{2}{*}{ Model } & \multicolumn{7}{|c|}{ Parameter estimates } \\
\hline & $\gamma_{00}$ & $\gamma_{01}$ & $\gamma_{10}$ & $\sigma^{2}$ & $\tau_{00}$ & $\tau_{11}$ & Effect \\
\hline $\begin{array}{l}\text { M1: null model } \\
\text { L1: } S A_{i j}=\beta_{0 j}+2_{i j} \\
\text { L2: } \beta_{0 j}=\gamma_{00}+U_{0 j}\end{array}$ & $3.23^{* *}$ & & & 0.39 & $0.037^{* *}$ & & \\
\hline $\begin{array}{l}\text { M2: relationship of inde- } \\
\text { pendent variable with } \\
\text { mediator }\end{array}$ & & & & & & & \\
\hline $\begin{array}{l}\text { L1: } I_{i j}=\beta_{0 j}+c_{i j} \\
\text { L2: } \beta_{0 j}=\gamma_{00}+\gamma_{01}\left(C_{i j}\right)+U_{0 j}\end{array}$ & 0.73 & $0.75^{* * *}$ & & 0.30 & $0.022^{* * *}$ & & \\
\hline $\begin{array}{l}\text { M3: relationship of med } \\
\text { with dependent variable } \\
\quad \text { L1: } S A_{i j}=\beta_{0 j}+\beta_{1 j}\left(I_{i j}\right)+c_{i j}\end{array}$ & & & & & & & \\
\hline $\begin{aligned} & \mathrm{L} 2: \beta_{0 j}=\gamma_{00}+U_{0 j} \\
& \beta_{l j}=\gamma_{10}+U_{l j} \\
& \text { M4: relationship of inde- } \\
& \text { pendent with depen- } \\
& \text { dent variable }\end{aligned}$ & $3.23^{* *}$ & & $0.41^{* *}$ & 0.34 & $0.027^{* *}$ & 0.002 & 0.13 \\
\hline $\begin{array}{l}\text { L1: } S A_{i j}=\beta_{0 j}+z_{i j} \\
\text { L2: } \beta_{0 j}=\gamma_{00}+\gamma_{01}\left(C_{i j}\right)+U_{0 j}\end{array}$ & $1.68^{*}$ & $0.42^{*}$ & & 0.40 & $0.032^{* *}$ & & 0.14 \\
\hline M5: mediation effect & & & & & & & \\
\hline $\mathrm{L} 1: S A_{i j}=\beta_{0 j}+\beta_{l j}\left(I_{i j}\right)+z_{i j}$ & & & & & & & \\
\hline
\end{tabular}


(Continued)

\begin{tabular}{cccccccc}
\hline \multirow{2}{*}{ Model } & \multicolumn{8}{c}{ Parameter estimates } \\
\cline { 2 - 7 } & $\gamma_{00}$ & $\gamma_{01}$ & $\gamma_{10}$ & $\sigma^{2}$ & $\tau_{00}$ & $\tau_{11}$ & Effect \\
\hline $\begin{array}{c}\text { L2: } \beta_{0 j}=\gamma_{00}+\gamma_{01}\left(C_{i j}\right)+U_{0 j} \\
\beta_{1 j}=\gamma_{10}+U_{l j}\end{array}$ & $2.78^{* *}$ & $\mathbf{0 . 1 2}$ & $0.40^{* *}$ & $\mathbf{0 . 3 4}$ & $0.029^{* *}$ & 0.003 & $\mathbf{0 . 1 5}$ \\
\hline${ }^{* *}$ & & & & & & & \\
\hline
\end{tabular}

Note: ${ }^{* *}$ indicates $p<0.01{ }^{*}$ indicates $p<0.05$;

$\mathrm{L} 1=$ Level 1; L2=Level 2; $\mathrm{SA}=$ employee satisfaction; $\mathrm{I}=$ individual learning; $\mathrm{C}=$ collective learning;

$\gamma_{00}=$ Intercept of Level 2 regression predicting $\beta_{0 \mathrm{j}} ; \gamma_{01}=$ Slope of Level 2 regression predicting $\beta_{0 \mathrm{j}} ; \gamma_{10}=$ Intercept of Level 2 regression predicting $\beta_{1 \mathrm{j}}$ (pooled Level 1 slopes); $\sigma^{2}=$ Variance in Level 1 residual (i.e. variance in $\mathrm{r}_{\mathrm{ij}}$ ); $\tau_{00}=$ Variance in Level 2 residual for models predicting $\beta_{0 j}$ (i.e., variance in $\mathrm{U}_{0}$ ); $\tau_{11}=$ Variance in Level 2 residual for models predicting $\beta_{1 \mathrm{j}}$;

effect $=\left(\sigma^{2}\right.$ of based model M4 $-\sigma^{2}$ of research model M5) $/ \sigma^{2}$ of based model M4.

Our results also show that individual learning acts as a full mediator between organization-level learning, inter-organizational learning, exploration learning and employee satisfaction (see Fig. 2). And individual learning acts as a full mediator between organizational level learning and emotional commitment, but has only partial mediation effect on the relationship between inter-organization learning, exploitation learning, exploration learning and emotional commitment (see Fig. 3). Therefore, the unit level dimensions of organizational learning must affect employee satisfaction through individual learning. Likewise, organizational level learning also affects emotional commitment through individual learning. However, inter-organization learning, exploitation learning and exploration learning can affect employee satisfaction directly and affect emotional commitment through the mediation of individual learning. As a result, the effects of organizational learning on employee satisfaction and emotional commitment are different. Hence Hypothesis 4 is supported.

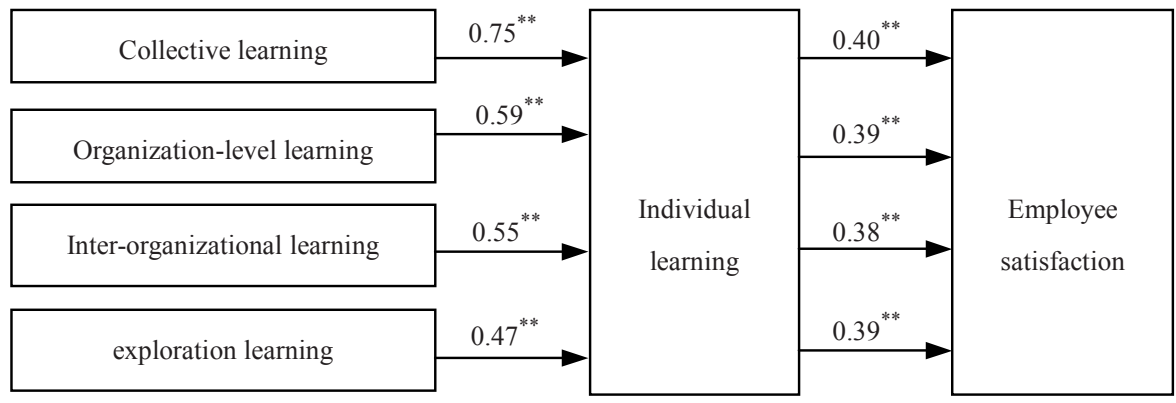

Fig. 2 Individual learning as a full mediator between unit-level dimensions of organizational learning and employee satisfaction

Note: ${ }^{* *}$ indicates $p<0.01,{ }^{*}$ indicates $p<0.05$. 


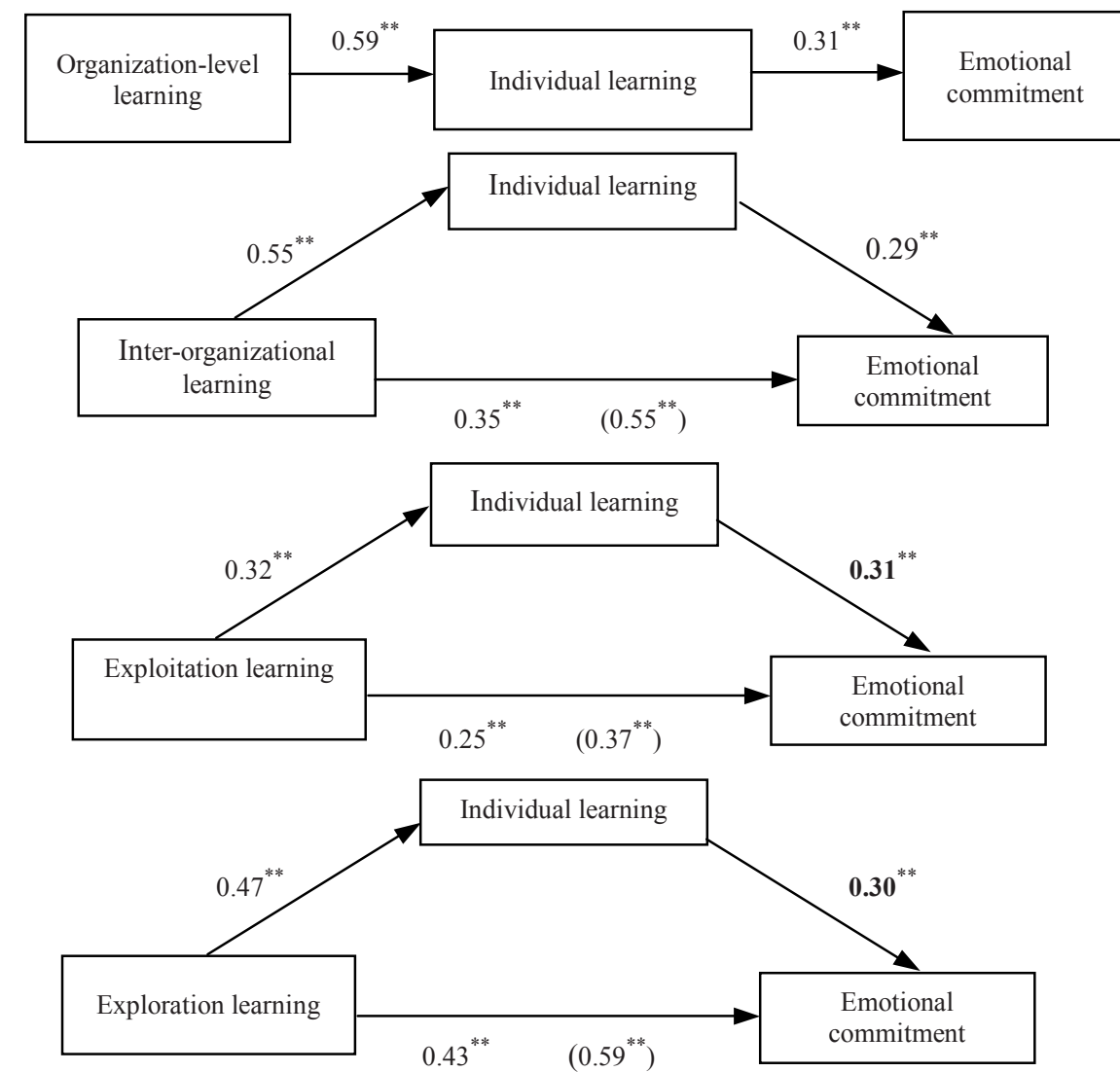

Fig. 3 Individual learning as a full and partial mediator between unit-level dimensions of organizational learning and emotional commitment

Note: ${ }^{* *}$ indicates $p<0.01,{ }^{*}$ indicates $p<0.05$. Numbers in the brackets refer to the index before the mediator is included.

\subsection{The moderating role of organizational learning}

HLM results also show that organization-level learning $\left(\gamma_{12}=-1.47, p<0.01\right)$ and exploitation learning $\left(\gamma_{15}=0.69, p<0.01\right)$ significantly affect the correlation $\left(\gamma_{10}=-0.43, p<0.001\right)$ between employee satisfaction and turnover intention; organization-level learning $\left(\gamma_{12}=-0.70, p<0.05\right)$ and exploitation learning $\left(\gamma_{15}=\right.$ $0.49, p<0.01)$ have significant effects on the correlation $\left(\gamma_{10}=-0.46, p<0.01\right)$ between emotional commitment and turnover intention. And these cross-level interaction results are showed in Fig. 4 and Fig. 5, where the relationships between employee satisfaction/emotional commitment and turnover intention are plotted for high and low organization-level learning (defined as +1 and -1 
standard deviation from the mean, respectively) (Aiken and West, 1991). In addition to plotting the interaction, we also conducted a simple slopes analysis (Aiken and West, 1991) which shows that the regression of turnover intention onto employee satisfaction within low level $(\beta=-0.33, t=-7.44, p<0.001)$ and high level $(\beta=-0.42, t=-8.37, p<0.001)$ of organization-level learning are all significant. Thus, the relationship between employee satisfaction and turnover intention is stronger in organizations with a higher level organizational learning
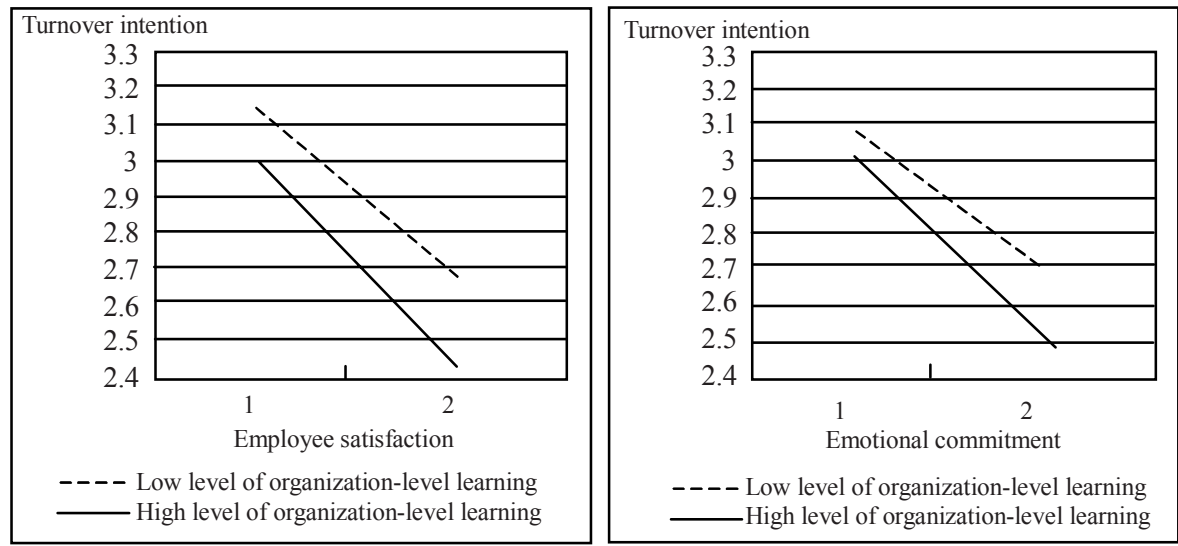

Fig. 4 Organization-level learning as moderator between job satisfaction/ emotional commitment and turnover intention

Note: 1 refers to low level of employee satisfaction / emotional commitment. 2 refers to high level of employee satisfaction / emotional commitment.
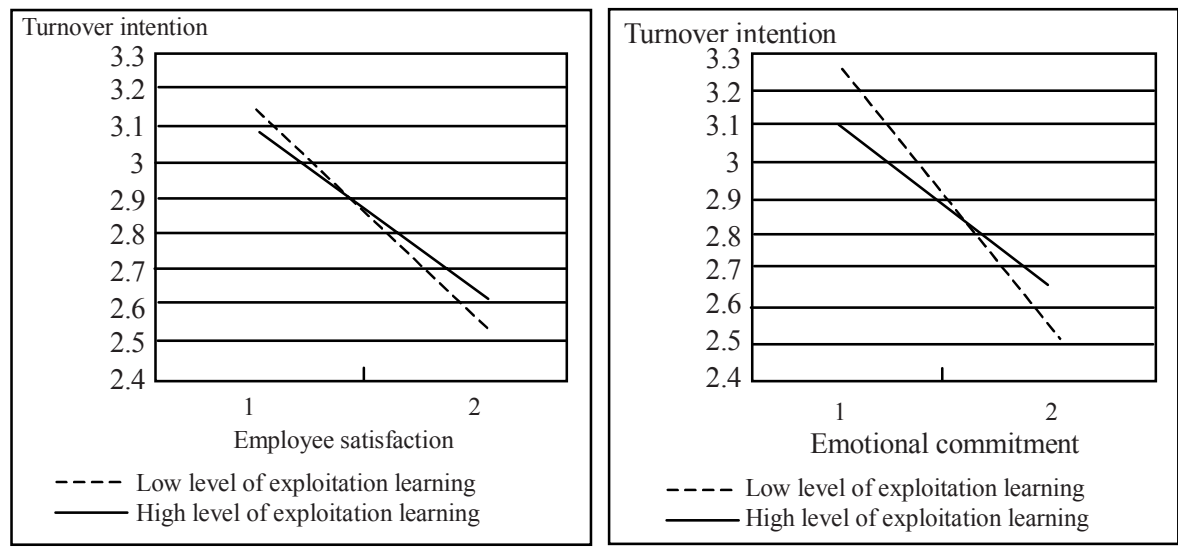

Fig. 5 Exploitation learning as moderator between job satisfaction/ emotional commitment and turnover intention

Note: 1 refers to low level of employee satisfaction / emotional commitment. 2 refers to high level of employee satisfaction / emotional commitment. 
and much weaker in organizations with lower organization-level learning. Similarly, the simple slope of the regression of turnover intention onto emotional commitment within low level $(\beta=-0.43, t=-9.78, p<0.001)$ and high level $(\beta=$ $-0.48, t=-9.67, p<0.001)$ of organization-level learning are all significant, and the relationship between emotional commitment with turnover intention is stronger in organizations with higher level organization-level learning and weaker in organizations with lower level organization-level learning.

The interaction between exploitation learning and employee satisfaction/ emotional commitment is showed in Fig. 5. The simple slope of the regression of turnover intention onto employee satisfaction within low level $(\beta=-0.42, t=$ $-9.65, p<0.001)$ and high level $(\beta=-0.33, t=-6.48, p<0.001)$ of exploitation learning are all significant. And the simple slope of the regression of turnover intention onto emotional commitment within low level $(\beta=-0.52, t=-12.17$, $p<0.001)$ and high level $(\beta=-0.41, t=-8.02, p<0.001)$ of exploitation learning are all significant. Therefore, the relationship between employee satisfaction/ emotional commitment and turnover intention is stronger in organizations with lower level exploitation learning and much weaker in organizations with higher level exploitation learning. H5 is partially supported.

And the regression results also demonstrate that the interaction between individual learning and employee satisfaction $(\beta=-0.11, p=0.687)$ on turnover intention is not significant, indicating that there are no moderation effects of individual learning on the relationship between employee satisfaction and turnover intention as well as the relationship between emotional commitment and turnover intention.

\section{Effective mechanisms of organizational learning on organization}

\subsection{Measures}

Organizational learning. In this study, organizational learning was measured by using the above 29 item questionnaire.

Organizational innovation. Calantone et al.'s (2002) 6-item scale of organizational innovation was chosen to measure employees' perception of their companies' innovative behaviors (Cronbach $\alpha=0.83$ )

Organizational financial performance. Calantone et al.'s (2002) 4-item scale of organizational financial performance is chosen to measure the extent to which employees evaluate their companies' financial performance. Participants were asked to use a 6-point Likert-type scale ( 1 stands for very low and 6 stands for very 
high) to report how well their enterprise performed financially during the previous 3 years in comparison with all other direct competitors. (Cronbach $\alpha=0.87$ ).

\subsection{Test of the validity of the unit level variables}

Organizational innovation and financial performance are unit-level variables. Therefore, the first step is to test the validity criteria for all the unit level variables. Results show that the indexes of $r_{w g}$ for organizational innovation and perceived organizational financial performance are 0.90 and 0.79 , respectively; and the indexes of $I C C$ (1) are 0.37 and 0.14 ; the indexes of $I C C$ (2) are 0.92 and 0.77; and the F values of ANOVA are 13.14 and 4.41, respectively. All these results suggest that there are sufficiently highly with-group homogeneity and between-groups variance to justify the average of individual-level data as the measure of these two unit level variables.

\subsection{Effects of organizational learning on organization}

As above, hierarchical regression analysis is used to analyze the data. First, we regress organizational innovation on organizational learning, and results show that there are significant effects of organizational learning on organizational innovation $(\beta=0.67, p<0.001)$ (see Table 8). Second, the results of HRA showed that organizational innovation capability affects organizational financial performance significantly $(\beta=0.39, p<0.001)$. Third, results of the second step of the third HRA showed that organizational learning affects perceived organizational financial performance significantly $(\beta=0.33, p<0.001)$, but when organizational innovation is controlled, there is no significant effect of organizational learning on organizational financial performance $(\beta=0.12$, $p>0.001)$, and there is significant effect of organizational innovation $(\beta=0.30$, $p<0.001)$. Therefore, organizational innovation acts as a full mediator between organizational learning and organizational financial performance.

Table 8 Hierarchical regression analysis of the mediation role of organizational innovation

\begin{tabular}{|c|c|c|c|c|c|c|c|}
\hline \multirow{3}{*}{ Variable } & \multicolumn{2}{|c|}{ Regression 1} & \multicolumn{2}{|c|}{ Regression 2} & \multicolumn{3}{|c|}{ Regression 3} \\
\hline & \multicolumn{2}{|c|}{$\begin{array}{l}\text { Organizational } \\
\text { innovation }\end{array}$} & \multicolumn{2}{|c|}{$\begin{array}{l}\text { Organizational } \\
\text { financial } \\
\text { performance }\end{array}$} & \multicolumn{3}{|c|}{$\begin{array}{l}\text { Organizational financial } \\
\text { performance }\end{array}$} \\
\hline & Step1 & Step2 & Step1 & Step2 & Step1 & Step2 & Step3 \\
\hline \multicolumn{8}{|l|}{ Control variable: } \\
\hline Company type & 0.09 & 0.07 & 0.03 & 0.01 & 0.03 & 0.03 & 0.01 \\
\hline Company size & $0.34^{* * *}$ & $0.19^{* * *}$ & $0.18^{* * *}$ & 0.05 & $0.18^{* * *}$ & 0.11 & 0.05 \\
\hline $\begin{array}{l}\text { Stage of development } \\
\text { Dependent variable: }\end{array}$ & -0.05 & 0.00 & -0.08 & -0.05 & -0.08 & -0.06 & -0.05 \\
\hline
\end{tabular}




\begin{tabular}{|c|c|c|c|c|c|c|c|}
\hline \multirow{3}{*}{ Variable } & \multirow{2}{*}{\multicolumn{2}{|c|}{$\begin{array}{c}\text { Regression } 1 \\
\begin{array}{c}\text { Organizational } \\
\text { innovation }\end{array}\end{array}$}} & \multirow{2}{*}{\multicolumn{2}{|c|}{$\begin{array}{c}\text { Regression 2 } \\
\text { Organizational } \\
\text { financial } \\
\text { performance }\end{array}$}} & \multicolumn{3}{|c|}{ Regression 3} \\
\hline & & & & & $\begin{array}{l}\text { Organiz } \\
\text { perfor }\end{array}$ & $\begin{array}{l}\text { tional fina } \\
\text { nance }\end{array}$ & cial \\
\hline & Step1 & Step2 & Step1 & Step2 & Step1 & Step2 & Step3 \\
\hline $\begin{array}{l}\text { Organizational } \\
\text { learning }\end{array}$ & & $0.67^{* * *}$ & & & & $0.33^{* * * *}$ & 0.12 \\
\hline Mediator: & & & & & & & \\
\hline $\begin{array}{c}\text { Organizational } \\
\text { innovation }\end{array}$ & & & & $0.39^{* * * *}$ & & & $0.30^{* * * *}$ \\
\hline$R^{2}$ & 0.093 & 0.529 & 0.026 & 0.162 & 0.026 & 0.127 & 0.170 \\
\hline$\Delta R^{2}$ & $0.093^{* * *}$ & $0.436^{* *}$ & $0.026^{* * *}$ & $0.136^{* *}$ & $0.026^{* *}$ & $0.101^{* *}$ & $0.042^{* *}$ \\
\hline$F$ & 31.20 & 844.90 & 5.76 & 103.75 & 5.76 & 74.11 & 32.66 \\
\hline
\end{tabular}

As shown in Fig. 6, organizational learning does not affect perceived organizational financial performance directly, but through the full mediation of organizational innovation. Thus $\mathrm{H} 6$ and $\mathrm{H} 7$ are supported and $\mathrm{H} 8$ is not supported.

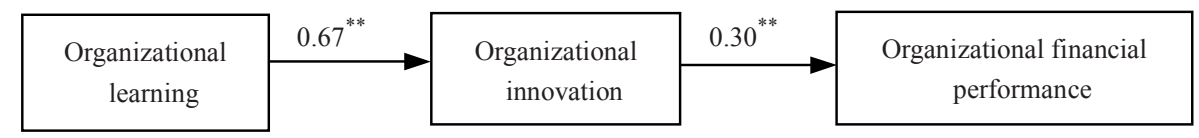

Fig. 6 Organizational innovation as a full mediator between organizational Note: ${ }^{* *}$ indicates $p<0.01,{ }^{*}$ indicates $p<0.05$. learning and organizational financial performance

\section{Discussion}

\subsection{Construct of organizational learning}

The above findings show that Chinese enterprise's organizational learning is composed of six dimensions, including four different learning levels and two information flows. Among the four learning levels, the individual level, collective level and organizational level have been accepted by almost all the researchers (Easterby-Smith et al., 2000), but the inter-organizational learning level is a pretty new level which has been described in some recent organizational learning literature Results of this study support their views. There are many theories on the two information flows in organizational learning, especially in March school. This study integrates the two views on organizational 
learning into one so that we can understand organizational learning process more deeply and completely.

At the same time, the results of organizational learning construct help lay a foundation for developing a more integrated theoretical model for organizational learning, which we believe can expand the previous Crossan's dynamic model (1999). In our model, inter-organizational learning is a necessary component of organizational learning. After China's entry into the WTO, Chinese enterprises are destined to face more fierce competitions in the global market, highlighting the importance of inter-organizational learning.

There are four characteristics in the organizational learning model. (1) Individual learning and collective learning emphasize the importance of employees in organizational learning; (2) Exploration learning and exploitation learning stress the importance of the knowledge or information processing; (3) Organizational level learning highlights the importance of nonhuman factors such as organizational strategy, organizational structure; (4) Inter-organizational learning pays attention to the importance of cross-organization learning, which is quite contrary to the common accepted view that organizational learning mostly happens within organizations.

\subsection{The effective mechanisms of organizational learning on individual employees}

The results on relationships between organizational learning and employee's satisfaction are consistent with the findings of Goh et al.'s (2002). And the results on relationships between organizational learning and emotional commitment are consistent with the conclusions of Howard's (2003). In addition, we also found that organizational learning can reduce employee's turnover intention. These proofs demonstrate that organizational learning can affect employee job attitudes directly.

For individual employees, this study demonstrates the mediation role of individual learning and the moderation roles of organizational-level learning and exploitation learning. Since there have been few empirical studies of organizational learning literature on the mediation of individual learning and the moderation of unit-level learning, these findings are one of the important contributions of this research.

For the mediation of individual learning, we argue that if the level of individual learning of employees is not high, the level of their satisfaction is not high in organizations with high level of other unit-level organizational learning dimensions. However, organization learning can directly affect employee emotional commitment, and the unit-level dimensions also indirectly affect employee emotional commitment through the mediation of individual learning. Therefore, the effects between organizational learning on employee satisfaction and on emotional commitment vary. Yet these findings need to be explored 
further. From the mediation of individual learning between unit-level learning and emotional commitment, we can see that there are some other mediators between them. Then, organizational learning also affects employee satisfaction and emotional commitment. However, only individual learning has effects on employee turnover intention, and the moderation of unit-level learning shows the indirect effects of organizational learning on turnover intention.

The study finds that in organizations with higher level of organization-level learning and lower level of exploitation learning, the relationships between employee satisfaction/emotional commitment and turnover intention were stronger. When an organization constantly adjusts its structure or strategy in accordance with changes of the outside environment and its development, employees are more likely to be more hopeful about the organization's prospect. These changes provide employees with the hope and future of organizations. As a result, employees are more willing to stay in organizations when they become more satisfied with and have strong commitment to their organizations. At the same time, when organizations emphasize few application of the update old and rigid organizational polices and strategies, this enables employees to enjoy larger freedom at work, and these can in turn motivate them to continue to stay in organizations more. On the contrary, if an organization sticks to constant application of the old organizational polices and strategy strategies, it may affect its employees' turnover intention, which make employees more likely to leave the organizations because this may impair its employees' working capabilities and enthusiasm. We can thus infer that organizational learning is not inherently positive or negative. Top managers in an enterprise need to and explicitly identify the challenge associated with managing the tension between exploration learning and exploitation learning. Results of the moderation of unit-level learning dimensions also show that human resource managers should be more aware of organizational learning so that they can better improve the employees' satisfaction and emotional commitment. We thus argue that in managing organizational learning, managers should pay more attention to fitting the organizational learning with other organizational factors such as employee's attitudes or organizational strategy. In so doing, the intervention effects of organizational learning on these factors can be positive.

\subsection{The effective mechanisms of organizational learning on organizations}

The findings of this study also show that there is an indirect effect of organizational learning on perceived organizational financial performance. This finding is quite inconsistent with some of the previous findings in literature. And this is one of the important contributions of this study. Based on this finding, we suggest that researchers and practitioners need to pay more attention to the 
effects of organizational learning on organizational financial performance. On the other hand, they should know that the effects can only be attained through a long time. This is why some hasty organizational intervention such as ERP and construction of "learning organization" fail to achieve expected benefits. As some prestigious thinkers have pointed out, learning faster than others is the only sustaining competitive advantage for an organization (De Geus, 1988; Senge, 1990), Our finding suggests that organizational learning and organizational innovation are "twins" in the development of an organization. This finding is especially important for Chinese enterprises that endeavor to enter the global market.

\subsection{Model of organizational learning effects on individuals and organizations}

Based on the above findings, we construct a theoretical model of organizational learning effects (Fig. 7). We believe such a model has many implications for the research of organizational leaning effective mechanisms in the future.

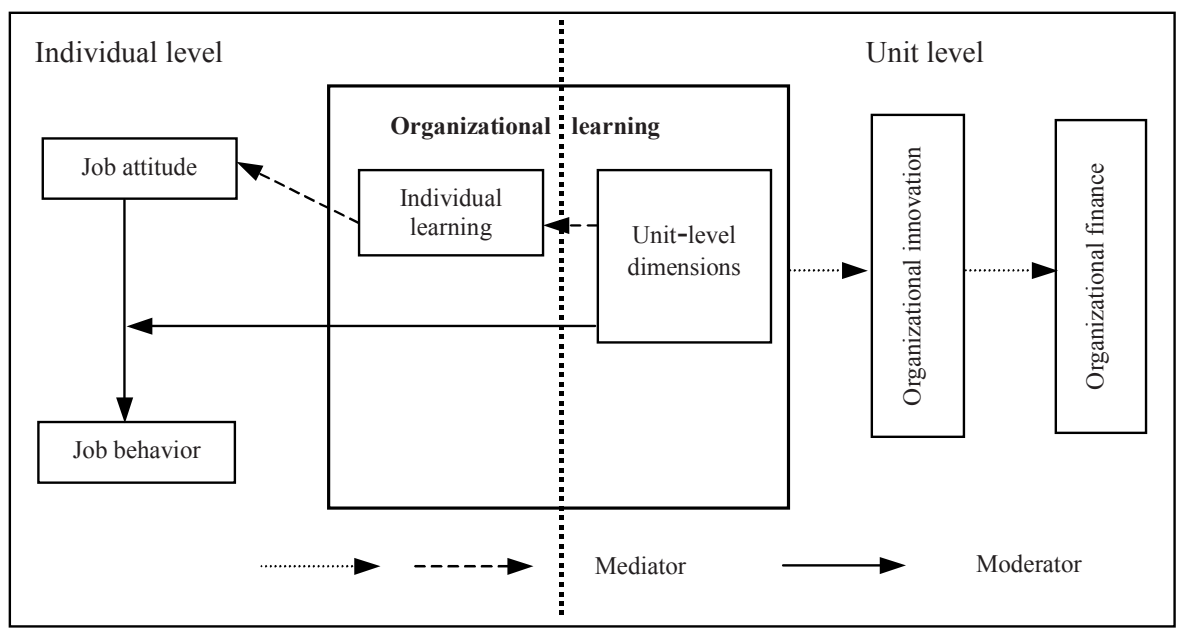

Fig. 7 The theory model of organizational learning effects

\section{Conclusions and future research directions}

Our findings in this article show that Chinese enterprise's organizational learning is a 6-dimension model consisting of inter-organizational learning, exploration learning, exploitation learning, organization-level learning, collective learning and individual learning. The reliability and validity of the questionnaire are high.

For the effects of organizational learning, individual learning is a full mediator 
between collective learning, organization-level learning, inter-organizational learning, exploration learning and employee satisfaction. Individual learning is a full mediator between organization-level learning and emotional commitment and a partial mediator between inter-organizational learning, exploration learning, exploitation learning and emotional commitment. There are significant negative effects of individual learning on employee turnover intention. For organizations with high level organization-level learning and low level exploitation learning, the relationships between employee satisfaction/emotional commitment and turnover intention are strong. And organizational learning affects perceived organizational financial performance through the full mediation of organizational innovation.

In the future, we can investigate organizational learning with other methods such as case study and longitudinal research to gain a fuller understanding of effective mechanisms of organizational learning. And the relationship between organizational learning and the objective organizational performance can also be explored if we were able to gain access to the real data of Chinese enterprise's financial performance.

\section{References}

Aiken L S, West S G (1991). Multiple Regression: Testing and Interpreting Interactions. Newbury Park, CA: Sage

Akgun A E, Lynn G S, Byrne J C (2003). Organizational leaning: Socio-cognitive framework. Human Relations, 56: 839-868

Ambrose M L, Schminke M (2003). Organization structure as a moderator of the relationship between procedural justice, interactional justice, perceived organizational support and supervisory trust. Journal of Applied Psychology, 88: 295-305

Argote L, Ingram P (2000). Knowledge transfer: A basis for competitive advantage in firms. Organizational Behavior and Human Decision Processes, 82(1): 150-169

Argyris C, Schön D A (1978). Organizational Learning: A Theory of Action Perspective. Reading, Massachusetts: Addison-Wesley

Baron R M, Kenny D A (1986). The moderator-mediator variable distinction in social psychological research: Conceptual, strategic, and statistical considerations. Journal of Personality and Social Psychology, 51: 1173-1182

Bartko J J (1976). On various intraclass correlation reliability coefficients. Psychological bulletin, 83: 762-765

Berends H, Boersma K, Weggeman M (2003). The structuration of organizational leaning. Human Relations, 56: 1035-1056

Bogenrieder I, Nooteboom B (2004). Learning groups: What types are there? A theoretical analysis and an empirical study in a consultancy firm. Organization Studies, 25: 287-313

Bogenrieder I (2002). Social architecture as prerequisite for organizational learning. Management Learning, 33: 197-212

Bollen K A (1989). Structural Equations with Latent Variables. New York: Wiley 
Bontis N, Crossan M, Hulland J (2002). Managing an organizational learning system by aligning stocks and flows. Journal of Management Studies, 39: 435-469

Brown J, Duguid P (1991). Organizational learning and communities of practice. Organization Science, 2: $40-57$

Bryk A, Raudenbush S W (1992). Hierarchical Linear Models for Social and Behavioral Research: Applications and Data Analysis Methods. Newbury Park, CA: Sage

Bunderson J S (2003). Management team learning orientation and business unit performance. Journal of Applied Psychology, 88: 552-560

Calantone R J, Cavusgil S T, Zhao Y (2002). Learning orientation, firm innovation capability, and firm performance. Industrial Marketing Management, 31: 515-524

Campion M A, Medsker G J, Higgs A C (1993). Relations between group characteristics and effectiveness: Implications for designing effective work groups. Personnel Psychology, 46: $823-850$

Chan D (1998). Functional relations among constructs in the same content domain at different levels of analysis: A typology of compositional models. Journal of Applied Psychology, 83: 234-236

Cook S, Yanow D (1993). Culture and organizational learning. Journal of Management Inquiry, 2: $373-390$

Crossan M, Lane H, White R, Djurfeldt L (1995). Organizational learning dimensions for a theory. The International Journal of Organizational Analysis, 3: 337-360

Crossan M, Lane H, White R (1999). An organizational learning framework: From intuition to institution. Academy of Management Review, 24: 522-537

Daft R L, Weick K E (1984). Toward a model of organizations as interpretation systems. Academy of Management Review, 9: 284-295

De Geus A P (1988). Planning as learning. Harvard Business Review, March-April: 70-74

DiBella A, Nevis E (1998). How Organization Learn. San Francisco: Jossey-Bass Publishers

Easterby-Smith M, Crossan M, Nicolini D (2000). Organizational learning: Debates past, present and future. Journal of Management Studies, 37(6): 783-796

Edmondson A (1999). Psychological safety and learning behavior in work teams. Administrative Science Quarterly, 44: 350-383

Ellinger A D, Ellinger A E, Yang B Y, Howton S W (2002). The relationship between the learning organization concept and firm's financial performance: An empirical assessment. Human Resource Development Quarterly, 13(1): 5-21

Ellis S, Shpielberg N (2003). Organizational leaning mechanisms and managers' perceived uncertainty. Human Relations, 56: 1233-1254

Fiol C M, Lyles M A (1985). Organizational learning. Academy of Management Review, 10: 803-813

Goh S, Richards G (1997). Benchmarking the learning capabilities of organizations. European Management Journal, 15(5): 575-583

Goh S C, Rhan P J (2002). Learning capability, organizational factors and firm performance. Third European Conference on Organizational Knowledge, Learning and Capabilities, Athens, Greece, April 5-6

Hackman J R (2003). Learning more by crossing levels: Evidence from airplanes, hospitals, and orchestras. Journal of Organizational Behavior, 24: 905-922

Hedberg R (1981). How organizations learn and unlearn. In: Nystrom P C, Starbuck W H (Eds.), Handbook of Organizational Design, 3-27. Oxford: Oxford University Press

Hofmann D A, Morgeson F P, Gerras S J (2003). Climate as a moderator of the relationship between leader-member exchange and content specific citizenship: Safety climate as an 
exemplar. Journal of Applied Psychology, 88: 170-178

Hofmann D A, Stetzer A (1996). A cross level investigation of factors influencing unsafe behavior and accidents. Personnel Psychology, 49: 307-339

Holmqvist M (2003). A dynamic model of intra- and interorganizational leaning. Organization Studies, 24: 95-123

Howard B D (2003). Organizational learning capacity in the context of the symlog most effective value profile. Dissertation-Abstracts-International, 64(3-B): 533

Huber G P (1991). Organizational learning: The contributing processes and the literatures. Organization Science, 2: 88-115

Hult G T M, Ferrell O C (1997). A global learning organizational structure and market information processing. Journal of Business Research, 40: 155-166

Hult G T M, David J (2003). Organizational learning as a strategic resource in supply management. Journal of Operations Management, 21: 541-556

Hurley R F, Hult G T M (1998). Innovation, market orientation, and organizational learning: An integration and empirical examination. Journal of Marketing, 62: 42-54

James L R, Demaree R G, Wolf G (1993). Rwg: An assessment of within group interrater agreement. Journal of Applied Psychology, 78: 306-309

James L R, Demaree R G, Wolf G (1984). Estimating within-group interrater reliability with and without response bias. Journal of Applied Psychology, 69: 85-98

James L R (1982). Agregation bias in estimates of perceptual agreement. Journal of Applied Psychology, 67: 219-229

Jerez-Go'mez P, Ce'spedes-Lorente J, Valle-Cabrera R (2005). Organizational learning capability: A proposal of measurement. Journal of Business Research, 58: 715-725

Kim D H (1993). The Link between individual and organizational learning. Sloan Management Review, 3: 37-50

Klein K J, Bliese P D, Kozlowski S W J, et al. (2000). Multilevel analytical techniques, In Klein K J, Kozlowski W J (eds.), Multilevel Theory, Research, and Methods in Organizations: Foundations, Extensions, and New Directions, 512-553. San Francisco: Jossey-Bass

Konovsky M A, Cropanzano R (1991). Perceived fairness of employee drug testing as a predictor of employee attitudes and job performance. Journal of Applied Psychology, 76: 698-707

Kozlowski S W J, Klein K J (2000). A multilevel approach to theory and research in organizations: Contextual, temporal, and emergent processes, In: Klein K J, Kozlowski W J (eds.), Multilevel Theory, Research, and Methods in Organizations: Foundations, Extensions, and New Directions, 3-90. San Francisco: Jossey-Bass

Lahteenmarki S, Toivonen J, Mattila M (2001). Critical aspects of organizational learning research and proposal for its measurement. British Journal of Management, 12: 113-129

Lane C (2001). Organizational learning in supplier networks. In: Dierkes M, Antal A B, Child J, Nonaka I (eds.), Handbook of Organizational Learning and Knowledge, 699-715. Oxford: Oxford University Press

March J G (1991). Exploration and exploitation in organizational learning. Organizational Science, 2: 71-87

Medsker G J, Willams L J, Hoahan P J (1994). A review of current practices for evaluating causal models of organizational behavior and human resources management research. Journal of Management, 20: 429-464

Meyer J P, Allen N J, Smith C A (1993). Commitment to organizations and occupations: Extension and test of a three-component conceptualization. Journal of Applied Psychology, 
78: $538-551$

Nonaka I, Takeuchi H (1995). The Knowledge Creating Company. London: Oxford University Press

Pawlowsky P (2001). The treatment of organizational learning in management science. In: Dierkes M, Antal A B, Child J, Nonaka I (eds.), Handbook of Organizational Learning and Knowledge, 61-81. Oxford: Oxford University Press

Pedler M, Burgoyne J, Boydell T (1991). The Learning Company: A Strategy for Sustainable Development. London: McGraw-Hill

Senge P (1990). The Fifth Discipline: The Art and Practice of the Learning Organization. Doubleday Currency, New York

Slater S F, Narver J C (1995). Market orientation and the learning organization. Journal of Marketing, 59: 63-74

Templeton G F, Lewis B R, Snyder C A (2002). Development of a measure for the organizational learning construct. Journal of Management Information Systems, 19: $175-218$

Tippins M J, Sohi R S (2003). It competency and firm performance: Is organizational learning a missing link? Strategic Management Journal, 24: 745-761

Tsui A S, Egan T D, O'Reilly C A (1992). Being different: Relational demography and organizational attachment. Administrative Science Quarterly, 37: 547-579

Yang B Y, Watkins K E, Marsick V J (2004). The construct of the learning organization: Dimensions, measurement, and validation. Human Resource Development Quarterly, 15(1): $31-55$

Yeung A, Ulrich D, Nason S, Glinow M (1999). Organizational Learning Capability. New York: Oxford University Press

Zohar D (2000). A group-level model of safety climate: Testing the effect of group climate on microaccidents in manufacturing jobs. Journal of Applied Psychology, 85: 587-596

陈国权, 李赞斌 (Chen Guoquan, Li Zanbin) (2002). 学习型组织中的学习主体类型与案例研究 (Studies on “learning entity" in learning organization: Types and case studies). 管理科学学 报, 4(5): 39-49

陈国权, 马萌 (Chen Guoquan, Ma Meng) (2000). 组织学习的过程模型研究(Studies on the process model of organizational learning). 管理科学学报, 3(3): 15-23

陈国权, 马萌 (Chen Guoquan, Ma Meng) (2001). 组织学习的模型、案例与实施方法研究 (Studies on organizational learning: Process model, case and implementation procedure). 中 国管理科学, 9(4): 65-74

陈国权, 郑红平 (Chen Guoquan) (2005). 组织学习影响因素、学习能力与绩效关系的实证研究 (Empirical Study on relationship among organizational influential factors, organizational learning capabilities and organizational performance). 管理科学学报, 8(1): 48-61

吴价宝 (Wu Jiabao) (2003). 组织学习能力测度 (The measurement of organizational learning capability). 中国管理科学, 11(4): 73-78

于海波, 方俐洛, 凌文铨 (Yu Haibo, Fang Liluo, Ling Wenquan) (2003). 我国企业组织学习取 向的初步研究 (A preliminary study of Chinese enterprise's learning orientation). 中国科学管 理, 11(6): 95-100

于海波, 方俐洛, 凌文铨 (Yu Haibo, Fang Liluo, Ling Wenquan) (2004). 组织学习的整合理论 模型 (Integrated organizational learning process model). 心理科学发展, 12(2): 246-255

于海波, 方俐洛, 凌文铨 (Yu Haibo, Fang Liluo, Ling Wenquan) (2004). 组织研究中的多层面 问题 (Issues on multilevel research of organizations). 心理科学进展, 12(3): 462-471 